\title{
Hubungan Personal Hygiene dan Sanitasi dengan Infeksi Soil Transmitted Helminths pada Anak Usia Sekolah Dasar disekitar TPA
}

\author{
Sarah Paramita Saskyarasmi' ${ }^{1}$, Octavia Permata Sari $^{2}$, Siti Munfiah $^{3}$ \\ ${ }^{1}$ Jurusan Kedokteran, Fakultas Kedokteran, Universitas Jenderal Soedirman \\ ${ }^{2}$ Departemen Parasitologi, Jurusan Kedokteran, Fakultas Kedokteran, Universitas Jenderal Soedirman \\ ${ }^{3}$ Ilmu Kesehatan Masyarakat, Jurusan Kedokteran, Fakultas Kedokteran, Universitas Jenderal Soedirman \\ Email: ${ }^{1}$ sarah.saskyarasmi@mhs.unsoed.ac.id ${ }^{2}$ Octavia.murdani@gmail.com \\ ${ }^{3}$ sitimunfiah@unsoed.ac.id
}

\begin{abstract}
Abstrak
Infeksi Soil Transmitted Helminths (STH) termasuk dalam "neglected tropical infectious disease". Prevalensi infeksi STH tertinggi didapatkan pada anak usia sekolah dasar. Terdapat berbagai faktor yang dihubungkan dengan tingginya kejadian infeksi STH pada anak usia sekolah dasar seperti, personal hygiene dan sanitasi yang buruk. Penelitian ini bertujuan untuk mengetahui hubungan personal hygiene dan sanitasi dengan infeksi STH pada anak usia sekolah dasar di sekitar TPA. Penelitian ini menggunakan analisis deskriptif dengan pendekatan kuantitatif dengan cara mengkaji 25 artikel yang telah terpilih sesuai kriteria yang ditentukan. Pencarian artikel dilakukan pada mesin pencari elektronik Google Scholar dan Directory of Open Access Journal menggunakan kata kunci, yaitu : Soil Transmitted Helminths, personal hygiene, sanitasi, anak usia sekolah dasar dan lingkungan TPA. Prevalensi infeksi STH pada anak usia sekolah dasar di sekitar TPA ditemukan 17,3\%-24,8\%. Sedangkan prevalensi infeksi STH pada anak usia sekolah dasar yang tidak tinggal di sekitar TPA ditemukan 6,8\%-48,32\%. 8 dari 11 penelitian menemukan adanya hubungan bermakna antara personal hygiene dengan infeksi STH pada anak usia sekolah dasar. 2 dari 4 penelitian menemukan adanya hubungan bermakna antara sanitasi dengan infeksi STH pada anak usia sekolah dasar. Daerah TPA berdampak pada kesehatan dan dapat menyebabkan berbagai penyakit salah satunya kecacingan. Beberapa literatur menunjukkan adanya hubungan bermakna antara personal hygiene dan sanitasi dengan infeksi STH pada anak usia sekolah dasar.
\end{abstract}

Kata kunci: Anak usia sekolah dasar, lingkungan TPA, Personal Hygiene, Sanitation, Soil Transmitted Helminths

\section{The Association Between Personal Hygiene and Sanitation with Soil Transmitted Helminthiasis in School-age Children among Landfills}

\begin{abstract}
Soil-Transmitted Helminthiasiasis is one of the "neglected tropical diseases". STH infection can infect all ages group. School-age childrens are at the highest risk with the highest prevalence that infected. There are some factors related to the incindence such as, the lack of awareness to maintain personal hygiene and the possibility of being exposed to poor sanitary conditions while doing activities or playing. This study aims to find the relation between personal hygiene and sanitation with soil transmitted helminthes infection among school-aged children around landfill area. This study used a descriptive analysis with a quantitative approach by collecting 25 articles according to predetermined criteria. A searched of the database Google Scholar and Directory of Open Access Journal was undertaken using the keywords Soil Transmitted Helminthiasis, personal hygiene, sanitation, school-aged children, landfill area. Various prevalence of STH infection was found. The prevalence of STH infection in school-aged children around landfills was 17.3-32.4\%, while Prevalence of STH infection in school-aged children not around landfill was 6.8-48.32\%. 8 out of 11 articles found a strong relationship between personal hygiene with Soil Transmitted Helminths infection among school-aged children. 2 out of 4 articles found a strong relationship between sanitation with Soil Transmitted Helminths infection among schoolaged children. Landfill areas affect health that caused various disease, such as helminthiasis. Most of the literature found a significant relationship between personal hygiene and sanitation with STH infection in schoolage children.
\end{abstract}

Keywords: Landfills, Personal Hygiene, Sanitation, School-age Children, Soil Transnitted Helminthiasis 


\section{PENDAHULUAN}

Infeksi cacing adalah kondisi masuknya parasit berupa cacing ke dalam tubuh manusia. Infeksi ini dapat berdampak turunnya status gizi, sistem imun, kecerdasan dan produktivitas dari penderita [1]. Telur dan larva cacing ini berkembang biak dengan baik di tanah yang basah dan lembab, karenanya kejadian infeksi cacing masih tinggi di negara tropis. Walaupun demikian infeksi ini termasuk dalam "Neglected Tropical Diseases" yaitu penyakit tropis yang terabaikan dan tidak dianggap penting karena efeknya yang baru terlihat dalam jangka waktu panjang [2]. Siklus hidup cacing ini memerlukan tanah untuk berkembang biak karenanya biasa disebut dengan cacing jenis Soil Transmitted Helminths (STH) yang terdiri dari, Ascaris lumbricoides, Trichuris trichiura, Strongyloides stercoralis, Necator americanus dan Anchylostoma duodenale [3].

World Health Organization (WHO) mencatat lebih dari 1,5 milyar penduduk atau $24 \%$ populasi dunia terinfeksi STH. Di Indonesia sendiri rata-rata prevalensi kecacingan sebesar 30\% [4]. Infeksi STH dapat dialami oleh semua kelompok usia, akan tetapi anak usia sekolah dasar menjadi kelompok usia paling berisiko terpapar dan terinfeksi oleh STH. Berbagai penelitian menunjukkan prevalensi infeksi STH pada anak usia sekolah dasar didapati lebih tinggi dari kelompok usia lainnya. Terdapat berbagai faktor yang dihubungkan dengan tingginya kejadian infeksi STH pada anak usia sekolah dasar antara lain, kurangnya kesadaran akan pentingnya menjaga personal hygiene dan kemungkinan risiko terpapar oleh kondisi sanitasi yang buruk pada saat beraktifitas maupun bermain.

Lingkungan sekitar TPA tergolong dalam lingkungan dengan sanitasi buruk, oleh karenanya menjadi sumber kontaminan berbagai agen penyakit, salah satunya infeksi kecacingan [5]. Sanitasi yang buruk ditambah dengan anak usia sekolah dasar yang masih belum dapat menjaga personal hygiene-nya mempermudah transmisi dari infeksi STH.

Tulisan ini merupakan sebuah narrative review yang mengkaji hubungan personal hygiene dan sanitasi dengan Infeksi STH pada anak usia sekolah dasar di sekitar TPA.

\section{METODE PENELITIAN}

Penelitian ini menggunakan analisis deskriptif dengan pendekatan kuantitatif. Penelitian ini mengkaji artikel hasil penelusuran yang didapatkan melalui mesin pencari elektronik Google Scholar dan Directory of Open Access Journal (DOAJ). Pencarian ini menggunakan kata kunci, yaitu : Infeksi Soil Transmitted Helminths pada anak usia sekolah dasar dan anak usia sekolah dasar di Tempat Pembuangan Akhir (TPA). Tahapan selanjutnya adalah screening yaitu, eliminasi jurnal yang tidak sesuai dengan kriteria inklusi dan eksklusi. Kriteria yang digunakan yaitu, memenuhi kesesuaian studi dan batasan tahun penerbitan artikel maksimum 5 tahun terakhir.

\section{HASIL DAN PEMBAHASAN}

Pada bagian ini dapat diuraikan mengenai hasil dari penelitian beserta pengujian yang telah dilakukan. Selain itu, disampaikan juga mengenai pembahasan dari penelitian maupun pengujian yang telah dilakukan.

Hasil dan pembahasan seharusnya merupakan bab yang paling banyak isinya pada sebuah paper. Isi Hasil dan Pembahasan dapat mencapai 50-65\% dari keseluruhan paper.

\subsection{Prevalensi Infeksi STH pada Anak Usia Sekolah Dasar}

Tulisan ini membahas prevalensi infeksi STH pada anak usia sekolah dasar dengan melibatkan 13 artikel penelitian. 5 penelitian dilakukan pada anak usia sekolah dasar yang berada di sekitar TPA, sedangkan 8 artikel penelitian dilakukan pada anak usia sekolah dasar yang tidak berada disekitar TPA. Didapatkan variasi prevalensi infeksi STH baik pada kelompok anak usia sekolah dasar di sekitar TPA maupun anak usia sekolah dasar yang tidak berada disekitar TPA.

Prevalensi infeksi STH pada anak usia sekolah dasar di sekitar TPA 17.3\%-32.4\%. Prevalensi terendah yaitu $17.3 \%$ didapatkan pada anak usia sekolah dasar di sekitar TPA Terjun Kecamatan Marelan, Medan, Sumatera Utara [6]. Hasil ini berbeda dengan hasil penelitian pada anak usia sekolah dasar di TPA Bantar Gebang, Bekasi dimana ditemukan prevalensi sebesar 32.4\%[7]. Angka prevalensi ini merupakan prevalensi tertinggi yang digunakan pada tulisan ini [7]. Tingginya temuan prevalensi infeksi ini disebabkan $71.6 \%$ responden bekerja sebagai pemulung[7]. Pemulung yang beraktifitas di TPA berisiko terpajan materi bahaya. Hal ini dikarenakan lingkungan TPA penuh dengan berbagai sampah dan limbah yang terkontaminasi agen penyakit [19]. Hasil yang tidak jauh berbeda ditemukan pada anak usia sekolah dasar di sekitar TPA di Nigeria yang menemukan prevalensi sebesar 32\%[8]. Tingginya angka prevalensi ini berhubungan dengan kebiasaan 
anak-anak yang sering buang air besar tidak menggunakan jamban. Kebiasaan ini termasuk dalam personal hygiene yang buruk yang dapat meningkatkan risiko infeksi kecacingan [20].

Tabel 1. Tabel Prevalensi

\begin{tabular}{llll}
\hline & \multicolumn{3}{c}{ TPA } \\
\hline Penulis & Total & Prevalensi & Lokasi \\
& Sampel & $(\%)$ & \\
Aritonang dan Siagian, 2017[6] & 52 & 17.3 & TPA Terjun, Medan \\
Winita et al, 2016 [7] & 74 & 32.4 & TPA Bantar Gebang, Bekasi \\
Atta et al, 2018 [8] & 110 & 24.5 & TPA di sekitar Zaidu Primary School, \\
& & & Nigeria \\
Ramayanti dan Makmun, 2018 [9] & 100 & 32 & TPA Sukawinatan, Palembang \\
Ramayanti dan Ghiffari, 2019 [10] & 109 & 24.8 & TPA Sukawinatan, Palembang \\
\hline & & Non TPA & \\
\hline Penulis & Total & Prevalensi & Lokasi \\
Sari et al, 2017 [11] & Sampel & $\mathbf{( \% )}$ & SD Susukan, Sumbang, Banyumas \\
Dewi et al, 2017 [12] & 44 & 6.8 & SDN 5 Delod Paken Tabanan \\
Mahmudah, 2017 [13] & 105 & 7.6 & SD Barengan, Teras, Boyolali \\
Darlan et al, 2019 [14] & 74 & 40.21 & SD Klumpang Kebun, Hamparan \\
& 39 & 25.6 & Perak, Deli Serdang \\
Prabandari et al, 2020 [15] & & & SD di Semarang \\
Suryantari et al, 2019 [16] & 149 & 48.32 & SD di Desa Ngis, Karangsalem, Bali \\
Yuwono et al, 2019 [17] & 138 & 10.1 & SD di Sorong, Papua Barat \\
Ohuche et al, 2020 [18] & 147 & 30.6 & Tenggara Sub Sahara Enugu Nigeria \\
\hline
\end{tabular}

Prevalensi sebesar 24.8\%ditemukan pada siswa SDN 188 Sukarame yang tinggal di sekitar TPA Sukawinatan Palembang[9]. Setahun setelahnya dilakukan penelitian serupa pada anak usia sekolah dasar di sekitar TPA Sukawinatan Palembang, hasilnya didapatkan prevalensi sebesar 24.5\% [10]. Kedua penelitian berada pada lokasi geografi yang berdekatan serta kebiasaan hidup yang tidak jauh berbeda. Kebiasaan adalah bagian dari budaya yang tumbuh dalam suatu masyarakat [21].

Penelitian pada anak usia sekolah dasar yang tidak berada disekitar TPA mendapatkan hasil prevalensi 6.8\%-48.32\%. Penelitian yang dilakukan pada siswa SD Susukan Kecamatan Sumbang Banyumas menemukan prevalensi sebesar 6.8\%[11]. Prevalensi ini merupakan prevalensi terendah. Hasil ini sesuai dengan penelitian yang dilakukan pada siswa SD 5 Delod Paken Tabanan yang menemukan prevalensi infeksi STH sebesar 7.6\% [12]. Rendahnya prevalensi yang ditemukan berhubungan dengan personal hygiene yang baik. Personal hygiene yang baik akan memutus mata rantai transmisi infeksi STH [22].

Prevalensi sebesar 10.1\% ditemukan pada anak usia sekolah dasar di Desa Ngis Karangsalem [16]. Hasil ini dihubungkan dengan pengetahuan perawatan diri dan kesehatan responden yang tidak memadai. Pengetahuan yang kurang mengenai perawatan diri dapat berpengaruh buruk bagi kesehatan [23].

Penelitian pada anak usia sekolah dasar yang tinggal di daerah kumuh perkotaan di Selatan Timur Sub Sahara Kota Enugu, Nigeria menemukan prevalensi infeksi STH sebesar 18.1\% [18]. Lokasi penelitian yang berada di daerah kumuh berhubungan dengan kejadian infeksi STH. Daerah kumuh dan padat penduduk mempermudah terjadinya invasi parasit khususnya cacing STH ke tubuh manusia [24].

Ditemukan hubungan yang kuat antara infeksi STH dengan personal hygiene dan sanitasi lingkungan pada siswa SD Negeri Klumpang Kebun Hamparan Perak Deli Serdang. Hampir seluruh responden yang terinfeksi kecacingan memiliki personal hygiene dan sanitasi lingkungan yang buruk. Masih adanya responden yang terinfeksi STH menyebabkan prevalensi yang ditemukan pada penelitian ini masih cukup tinggi yaitu sebesar $25.6 \%[14]$.

Prevalensi sebesar 30.6\% ditemukan pada siswa SD di Kabupaten Sorong [17]. Sejalan dengan temuan pada siswa SD Barengan kecamatan Teras Kabupaten Boyolali yang menemukan prevalensi infeksi STH yang tinggi yaitu sebesar $40.21 \%$ [13]. Kedua penelitian ini menemukan tingginya prevalensi infeksi STH berhubungan dengan sanitasi lingkungan dimana sebagian besar responden memiliki sanitasi buruk. Tingkat sanitasi yang buruk ini akan meningkatkan risiko penyebaran penyakit khususnya infeksi kecacingan [2].

Penelitian pada siswa dari 3 sekolah dasar di Kota Semarang menemukan prevalensi infeksi STH yang sangat tinggi yaitu sebesar $48.32 \%$ [15]. Tingginya prevalensi ini disebabkan pada penelitian ini ditemukan berbagai faktor yang berhubungan erat dengan kejadian infeksi STH seperti, sebagian besar responden yang 
gemar bermain di tanah, lingkungan sekolah yang masih banyak beralaskan tanah, serta sebagian besar responden yang berasal dari kelompok sosial ekonomi menengah ke bawah. Kejadian kecacingan pada anak berhubungan erat dengan sanitasi lingkungan buruk, tingkat pendidikan orang tua, kondisi sosial ekonomi, dan kebiasaan hidup sehat yang belum membudaya[25].

\subsection{Hubungan Personal Hygiene dan Sanitasi dengan Infeksi Soil Transmitted Helminths pada Anak Usia Sekolah Dasar}

Tabel 2. Tabel Hubungan Personal Hygiene dengan Infeksi Soil Transmitted Helminths pada Anak

\begin{tabular}{|c|c|}
\hline \multicolumn{2}{|r|}{ Personal Hygiene } \\
\hline Nama Penulis & Hasil Penelitian \\
\hline Ramayanti dan Ghiffari, 2019 [10] & $\begin{array}{l}\text { Terdapat hubungan bermakna antara infeksi STH dengan kebiasaan cuci tangan sebelum makan } \\
(\mathrm{p}=0.001) \text {, kebiasaan cuci tangan setelah BAB }(\mathrm{p}=0.028) \text { serta kebiasaan penggunaan alas kaki } \\
(\mathrm{p}=0.013) \text {. }\end{array}$ \\
\hline Darlan et al, 2019 [14] & $\begin{array}{l}\text { Terdapat hubungan antara personal hygiene dan infeksi STH pada siswa SD Klumpang Kebun, } \\
\text { Deli Serdang }(\mathrm{p}=0.000) \text {. }\end{array}$ \\
\hline Dewi et al, 2017 [12] & $\begin{array}{l}\text { Terdapat hubungan bermakna antara infeksi STH dengan personal hygiene, yaitu: } \\
\text { a. Aktifitas mencuci tangan }(\mathrm{p}=0.001) \\
\text { b. Kontak dengan tanah }(\mathrm{p}=0.003)\end{array}$ \\
\hline Andini dan Utomo, 2017[26] & $\begin{array}{l}\text { Terdapat hubungan antara personal hygiene dan infeksi kecacingan pada murid MI Ma arif } \mathrm{Nu} \\
\text { Banteran }(\mathrm{p}=0.000)\end{array}$ \\
\hline Suraini et al, 2018 [27] & Terdapat hubungan antara personal hygiene dengan infeksi STH dengan p value $<0.05$ \\
\hline Aisyah et al, 2019 [28] & $\begin{array}{l}\text { Personal hygiene berpengaruh dengan infeksi STH, didapatkan hasil kekuatan sedang dengan } \\
\text { nilai Nagelkerke R Square sebesar } 0.666 \text {. Faktor berpengaruh yaitu kebersihan kuku kaki, } \\
\text { pemakaian alas kaki, dan kebiasaan cuci tangan. }\end{array}$ \\
\hline Pratama et al, 2018 [29] & $\begin{array}{l}\text { Terdapat hubungan bermakna antara perilaku BAB dengan infeksi STH pada siswa SD } 2 \\
\text { Padangbulia }(\mathrm{p}=0.001) \text {. }\end{array}$ \\
\hline Wulandari et al, 2017 [30] & $\begin{array}{l}\text { Terdapat hubungan bermakna antara personal hygiene pada anak usia sekolah dasar di wilayah } \\
\text { kerja Puskesmas Punggur: }\end{array}$ \\
\hline & a. Kebiasaan BAB $(\mathrm{p}=0.0007)$ \\
\hline & Penggunaan alas kaki $(\mathrm{p}=0.041)$ \\
\hline & Kebiasaan cuci tangan $(\mathrm{p}=0.003)$ \\
\hline & d. $\quad$ Kebersihan kuku $(\mathrm{p}=0.000)$ \\
\hline Aritonang dan Siagian, 2017 [6] & $\begin{array}{l}\text { Tidak terdapat hubungan bermakna antara personal hygiene dengan infeksi STH pada anak usia } \\
\text { sekolah dasar di TPA Terjun, Medan }(\mathrm{p}>0,05) \text {. }\end{array}$ \\
\hline Sari et al, 2017 [11] & $\begin{array}{l}\text { Tidak terdapat hubungan bermakna antara personal hygiene dengan infeksi STH pada siswa SD } \\
\text { Susukan, Banyumas }(\mathrm{p}=0.197) \text {. }\end{array}$ \\
\hline Farida , 2019 [31] & $\begin{array}{l}\text { Tidak terdapat hubungan bermakna antara personal hygiene dengan infeksi STH pada siswa } \\
\text { SDN } 1 \text { Kedamean : }\end{array}$ \\
\hline & a. $\quad$ Minum obat cacing $(\mathrm{p}=0.619)$ \\
\hline & Cuci tangan $(\mathrm{p}=0.538)$ \\
\hline & Memakai alas kaki $(\mathrm{p}=0.433)$ \\
\hline & d. $\quad$ Memotong kuku $(\mathrm{p}=0.671)$ \\
\hline
\end{tabular}

Tulisan ini menggunakan 11 artikel penelitian untuk mengetahui tingkat personal hygiene pada anak usia sekolah dasar. Tingkat personal hygiene diambil melalui kuesioner bervariasi yang hasilnya dikelompokkan ke dalam kategori baik maupun buruk. Ditemukan 8 artikel yang menemukan adanya hubungan bermakna antara personal hygiene dengan infeksi STH, sedangkan 3 artikel lainnya tidak menemukan adanya hubungan bermakna antara personal hygiene dengan infeksi STH. Lebih banyak artikel yang menemukan adanya hubungan bermakna antara kedua variabel menunjukkan personal hygiene menjadi masalah yang dapat meningkatkan risiko infeksi STH.

Ditemukan adanya hubungan bermakna antara kebiasaan mencuci tangan dengan Infeksi STH pada anak di wilayah kerja Puskesmas Punggur dan Desa Ngis dengan hasil nilai " $p$ " yang ditemukan berturut-turut 0.003, dan 0.001 [12]-[30]. Sesuai penelitian pada anak di TPA Sukawinatan Palembang yang menemukan adanya hubungan bermakna antara infeksi STH dengan kebiasaan mencuci tangan sebelum makan $(\mathrm{p}=0.001)$ dan kebiasaan mencuci tangan setelah BAB $(\mathrm{p}=0.028)$ [10]. Hasil ini sejalan dengan temuan adanya hubungan kebiasaan cuci tangan dengan infeksi STH pada siswa sekolah dasar di Kartasura dengan hasil kekuatan sedang dengan nilai Nagelkerke R Square sebesar 0.666 [28]. Kebiasaan mencuci tangan sangat penting untuk menekan angka infeksi kecacingan. Kebiasaan ini akan membersihkan telur cacing yang menempel setelah kontak dengan lingkungan yang tercemar sehingga transmisi dari infeksi dapat dicegah [22].

Adanya hubungan bermakna antara kebersihan kuku dengan infeksi STH pada anak usia sekolah dasar ditemukan pada penelitian yang dilakukan pada anak di wilayah kerja Puskesmas Punggur dengan hasil nilai $\mathrm{p}=0.000[30]$. Sejalan dengan penelitian yang menemukan hubungan kebersihan kuku kaki dengan infeksi STH pada siswa sekolah dasar di Kartasura dengan nilai Nagelkerke R Square sebesar 0.666 [28]. Kebersihan kuku 
sangat berpengaruh dengan kejadian infeksi STH. Adanya kontak dengan lingkungan tercemar dapat menyisakan telur cacing yang menempel di kuku. Telur ini dapat masuk kedalam tubuh dan menginfeksi manusia [32].

Adanya hubungan bermakna antara penggunaan alas kaki dengan infeksi STH ditemukan pada anak usia sekolah dasar disekitar TPA Sukawinatan $(\mathrm{p}=0.013)$ [10]. Hasil ini sejalan dengan penelitian pada siswa sekolah dasar di Kartasura yang menemukan hasil nilai Nagelkerke R Square sebesar 0.666[28]. Kebiasaan masyarakat yang sering tidak menggunakan alas kaki dapat memperbesar risiko dari infeksi kecacingan. Penggunaan alas kaki dapat menghindari transmisi dari telur atau larva cacing melalui perantaraan kulit [33].

Terdapat hubungan bermakna antara kebiasaan BAB dengan infeksi STH $(\mathrm{p}=0.0007)$ ditemukan pada anak usia sekolah dasar di wilayah kerja Puskesmas Punggur[30]. Sejalan dengan hal tersebut penelitian yang menemukan adanya hubungan bermakna antara kebiasaan BAB diluar WC dengan infeksi STH $(p=0.001)$ pada siswa SD 2 Padangbulia [29]. Kebiasaan defekasi berhubungan erat dengan infeksi STH dikarenakan siklus hidup cacing dan penularan infeksi melibatkan tanah. Telur dan larva cacing akan berada di tanah sehingga infeksi dapat terjadi pada manusia yang kontak dengan tanah tercemar tersebut. Kontak dengan tanah dapat terjadi saat manusia BAB sembarangan [20].

Ditemukan adanya hubungan yang bermakna antara personal hygiene secara umum dengan infeksi STH dengan hasil nilai " $p$ " berturut-turut $0.000,0.012,0.0001$ dan $0.000[26]-$ [12]- [14]. Beberapa penelitian diatas menemukan dengan diterapkannya perbaikan personal hygiene dapat menjadi upaya pencegahan infeksi STH pada anak usia sekolah dasar. Namun demikian, sulitnya menjaga personal hygiene anak menjadi penyebab utama infeksi STH masih banyak dialami oleh anak khususnya anak usia sekolah dasar [23].

Berbeda dengan temuan pada penelitian diatas, terdapat penelitian yang tidak menemukan adanya hubungan bermakna antara personal hygiene dengan infeksi STH dengan hasil nilai "p" berturut-turut adalah 0.197 dan 0.8 [11]- [6]. Hasil ini sesuai dengan penelitian pada siswa SDN 1 Kedamean yang menemukan tidak adanya hubungan bermakna antara infeksi STH dengan kebiasaan cuci tangan $(\mathrm{p}=0.538)$, kebiasaan pemakaian alas kaki $(\mathrm{p}=0.433)$, kebiasaan memotong kuku $(\mathrm{p}=0.671)$, kebiasaan minum obat cacing $(\mathrm{p}=0.619)$ [31]. Tidak ditemukannya hubungan bermakna antara personal hygiene dengan infeksi STH dapat disebabkan oleh telah dilakukannya pengelolaan faktor risiko dan pencegahan dari infeksi. Hal ini terlihat dari sebagian besar anak yang sudah memiliki kebiasaan personal hygiene yang baik. Kebiasaan personal hygiene baik ini sangat penting untuk dimiliki sehingga infeksi tidak dapat terjadi. Meskipun anak-anak usia sekolah dasar menjadi kelompok usia rentan terinfeksi STH, namun dengan adanya kebiasaan personal hygiene baik maka transmisi dari infeksi tidak dapat terjadi [22].

Tabel 3. Hubungan Sanitasi dengan Infeksi Soil Transmitted Helminths pada Anak

\begin{tabular}{|c|c|}
\hline \multicolumn{2}{|r|}{ Sanitasi } \\
\hline Nama Penulis & Hasil Penelitian \\
\hline $\begin{array}{l}\text { Kusumawardani } \\
\text { et al, } 2019 \text { [34] }\end{array}$ & $\begin{array}{l}\text { Tidak terdapat hubungan bermakna antara kejadian infeksi STH dengan sanitasi lingkungan } \\
(\mathrm{p}=0.165) .\end{array}$ \\
\hline Sofiana et al, & Tidak terdapat hubungan bermakna antara infeksi STH dengan kepadatan lalat ( $\operatorname{sig}=0.307)$, \\
\hline 2020 [35] & Tempat Pembuangan Akhir (sig=0.207), jenis lantai $(\operatorname{sig}=0.330)$. \\
\hline Ramayanti dan & Terdapat hubungan bermakna antara infeksi STH dengan penggunaan jamban $(p=0.021)$. \\
\hline Ghiffa & \\
\hline$[10]$ & \\
\hline $\begin{array}{l}\text { Mahmudah, } \\
2017[13]\end{array}$ & $\begin{array}{l}\text { Terdapat hubungan bermakna antara infeksi STH dengan sanitasi lingkungan rumah pada } \\
\text { anak sekolah dasar }(\mathrm{p}=0.000) \text {. }\end{array}$ \\
\hline Darlan et al, & Terdapat hubungan bermakna antara infeksi STH dengan kondisi sanitasi lingkungan $(\mathrm{p}=$ \\
\hline 2019 [14] & \\
\hline
\end{tabular}

Sanitasi merupakan salah satu faktor yang berperan penting terhadap kejadian infeksi STH. Tulisan ini menggunakan 5 artikel penelitian untuk mengetahui hubungan sanitasi dengan infeksi Soil Transmitted Helminths pada siswa sekolah dasar. Ditemukan 3 artikel yang menemukan hasil adanya hubungan bermakna antara sanitasi dengan kejadian infeksi STH sedangkan 2 artikel lainnya tidak menemukan adanya hubungan bermakna antara kedua variabel.

Penelitian yang dilakukan pada siswa pada siswa SD Barengan Boyolali dan siswa SD di Klumpang Kebun Deli Serdang menemukan adanya hubungan yang bermakna antara infeksi STH dengan kondisi sanitasi lingkungan dengan nilai $\mathrm{p}=0.000$ [13]-[14]. Sejalan dengan penelitian pada siswa SD di TPA Sukawinatan Palembang yang menemukan adanya hubungan bermakna antara infeksi STH dengan penggunaan jamban ( $\mathrm{p}=$ 0.021) [10]. Adanya hubungan yang bermakna antara infeksi STH dengan sanitasi menunjukkan faktor lingkungan berperan penting dan menjadi faktor penentu dari distribusi infeksi. Hal ini dikarenakan penyebaran 
penyakit yang berhubungan dengan siklus hidup dari cacing STH. Perbaikan dari kondisi sanitasi dapat mencegah penularan infeksi ini. Kondisi sanitasi yang memenuhi syarat dapat memberikan proteksi tambahan untuk memutus rantai transmisi [36].

Penelitian yang dilakukan siswa SD di Jember menunjukkan tidak adanya hubungan bermakna antara kejadian infeksi STH dengan sanitasi lingkungan $(\mathrm{p}=0.165)$ [34]. Lebih lanjut, tidak ditemukan adanya hubungan antara sanitasi dengan kejadian infeksi STH juga ditemukan pada penelitian yang dilakukan anak usia sekolah dasar di Puskesmas Moyudan dengan variabel yang diukur yaitu, kepadatan lalat (sig=0.348), ketersediaan toilet $(\mathrm{sig}=0.307)$, Tempat Pembuangan Akhir $(\mathrm{TPA})(\operatorname{sig}=0.207)$, jenis lantai $(\operatorname{sig}=0.330)[35]$.

Tidak adanya hubungan bermakna antara sanitasi dengan infeksi STH pada penelitian disebabkan infeksi STH tidak hanya disebabkan oleh faktor lingkungan. Terdapat faktor lain yang berpengaruh dengan kejadian infeksi STH yaitu personal hygiene. Hasil penelitian menunjukkan, seseorang yang memiliki kebiasaan personal hygiene yang baik dapat menurunkan risiko terkena infeksi STH meskipun tinggal di daerah dengan sanitasi buruk[34].

\subsection{Dampak Keberadaan TPA}

Tabel 3. Dampak Keberadaan TPA

\begin{tabular}{|c|c|c|}
\hline Penulis & Lokasi & Dampak \\
\hline Yusmiati et al, 2017 [37] & $\begin{array}{l}\text { TPA Muara Fajar } \\
\text { Pekanbaru }\end{array}$ & $\begin{array}{l}\text { Perkembangbiakan berbagai macam organisme } \\
\text { dan vektor penyebab penyakit salah satunya } \\
\text { kecacingan. }\end{array}$ \\
\hline Simon-Oke, 2020 [38] & TPA di Ondo, Nigeria & $\begin{array}{l}\text { Perkembangbiakan berbagai parasit termasuk } \\
\text { cacing jenis STH }\end{array}$ \\
\hline $\begin{array}{l}\text { Ugochi dan Agbolade, } \\
2020 \text { [39] }\end{array}$ & TPA di Ogun, Nigeria & $\begin{array}{l}\text { Munculnya lalat yang membantu penyebaran } \\
\text { infeksi STH }\end{array}$ \\
\hline Muslimah et al, 2019 [40] & Makassar & $\begin{array}{l}\text { Ditemukannya } 83.6 \% \text { pekerja truk sampah } \\
\text { positif kecacingan oleh jenis STH. Terdapat } \\
\text { hubungan bermakna antara sikap dengan } \\
\text { kejadian kecacingan pada pekerja }(\mathrm{p}=0.023) \text {. }\end{array}$ \\
\hline Winita et al, 2016 [7] & $\begin{array}{l}\text { TPA Bantar Gebang } \\
\text { Bekasi. }\end{array}$ & $\begin{array}{l}\text { Ditemukannya prevalensi kecacingan oleh jenis } \\
\text { STH yang tinggi. Tingginya angka infeksi } \\
\text { kecacingan disebabkan lingkungan TPA } \\
\text { menjadi tempat ideal untuk perkembangan dan } \\
\text { transmisi cacing. Sanitasi lingkungan yang } \\
\text { buruk dilihat dari banyaknya tumpukan sampah } \\
\text { yang tersebar di beberapa tempat disertai } \\
\text { kebiasaan warga terutama anak yang memiliki } \\
\text { personal hygiene buruk seperti BAB } \\
\text { sembarangan memudahkan terjadinya infeksi. }\end{array}$ \\
\hline $\begin{array}{l}\text { Ramayanti dan Ghiffari, } \\
2019 \text { [10] }\end{array}$ & $\begin{array}{l}\text { TPA Sukawinatan } \\
\text { Palembang }\end{array}$ & $\begin{array}{l}\text { 1. Pencemaran Udara } \\
\text { 2. Munculnya berbagai vektor penyakit }\end{array}$ \\
\hline
\end{tabular}

Tempat Pembuangan Akhir (TPA) sampah adalah Tempat Pembuangan Akhir (TPA) sampah adalah sarana fisik tempat berlangsungnya kegiatan pembuangan akhir sampah. Sampah dari TPA bisa berasal dari Tempat Penampungan Sementara (TPS) ataupun langsung dari sumbernya. Tujuan dibuatnya TPA adalah untuk mengurangi timbunan sampah di masyarakat [41]. Timbunan sampah ini akan menghasilkan berbagai gas dan cairan yang berpotensi menimbulkan pencemaran. Salah satu cairan yang dihasilkan adalah air lindi [42]. Air lindi ini mengandung zat pencemar seperti kesadahan, mangan, nitrit, besi dan logam berat yang dapat mengalir dan menyebabkan pencemaran air permukaan maupun air tanah. Timbunan sampah juga akan menyebabkan pembusukan sampah yang menghasilkan gas Metana $(\mathrm{CH} 4)$ dan gas Hidrogen Sulfida (H2S) yang berbau busuk dan mengundang berbagai vektor penyakit seperti tikus, lalat, dan nyamuk [43]. 
Penelitian yang dilakukan pada TPA di Ogun Nigeria menemukan keberadaan TPA berdampak pada meningkatnya kepadatan lalat yang membantu penyebaran infeksi STH [39]. Lalat ini membawa telur/ kista cacing dari tanah disekitar TPA kemudian menempel di makanan. Infeksi dapat terjadi saat manusia secara tidak sengaja menelan telur/kista cacing dari makanan yang terkontaminasi tersebut. Meningkatnya kepadatan lalat akan membantu perkembangan telur dan larva cacing yang berakibat pada tercemarnya tanah disekitar TPA [38].

Hasil penelitian yang dilakukan di TPA Muara Fajar Pekanbaru menemukan keberadaan TPA berdampak pada kesehatan masyarakat sekitarnya. Adanya TPA menyebabkan berkembangnya berbagai macam organisme dan vektor penyebab penyakit salah satunya kecacingan [37]. TPA Muara Fajar Pekanbaru menggunakan metode open dumping dimana metode ini termasuk dalam metode pengelolaan sampah yang kurang memuaskan. Keberadaan TPA harus dikelola dengan baik agar tidak menimbulkan dampak buruk bagi masyarakat [44].

Dampak buruk TPA bagi kesehatan diperkuat dengan ditemukannya 83.6\% pekerja truk sampah di Manado positif kecacingan oleh cacing jenis STH. Penelitian ini menemukan adanya hubungan bermakna antara sikap pekerja dengan kejadian kecacingan pada pekerja truk sampah di Makassar $(\mathrm{p}=0.023)$ [40].

Lingkungan sekitar TPA yang dapat meningkatkan risiko infeksi STH akan semakin berdampak buruk bagi anak usia sekolah dasar dimana diketahui anak usia sekolah dasar merupakan kelompok umur dengan prevalensi STH tertinggi. Penelitian pada anak usia sekolah dasar di TPA Bantar Gebang menemukan prevalensi infeksi yang tinggi sebesar $32.4 \%$. Penelitian ini menyebutkan tingginya angka infeksi STH disebabkan lingkungan TPA menjadi tempat ideal untuk perkembangan dan transmisi cacing. Sanitasi lingkungan yang buruk dilihat dari banyaknya tumpukan sampah yang tersebar di beberapa tempat disertai kebiasaan anak yang memiliki personal hygiene buruk seperti BAB sembarangan memudahkan terjadinya infeksi [7].

Sesuai dengan penelitian yang dilakukan pada anak usia sekolah dasar di TPA Sukawinatan Palembang yang menemukan lingkungan TPA menyebabkan timbulnya pencemaran udara dan berkembangnya vektor penyakit yang berkontribusi pada penyebaran infeksi STH [10]. Meskipun demikian, belum ada penelitian yg menguji hubungan antara keberadaan TPA dengan infeksi STH pada anak usia sekolah dasar, sehingga diperlukan penelitian lebih lanjut untuk membuktikan teori ini.

\section{KESIMPULAN}

Beberapa literatur yang digunakan menunjukkan adanya hubungan bermakna antara personal hygiene dan sanitasi dengan infeksi STH pada anak usia sekolah dasar. Prevalensi infeksi STH ditemukan bervariasi baik pada anak disekitar TPA maupun tidak tinggal disekitar TPA. Direkomendasikan untuk dilakukan pengelolaan faktor yang berhubungan dengan infeksi STH seperti, meningkatkan sarana sanitasi yang memenuhi syarat dan membiasakan personal hygiene yang baik dalam kehidupan sehari-hari.

\section{DAFTAR PUSTAKA}

[1] Ditjen PP\&PL. Profil Pengendalian Penyakit dan Penyehatan Lingkungan Tahun 2012. Jakarta: Kementerian Kesehatan Republik Indonesia, 2013.

[2] N.M. Muslimawati dan P. Widayani, "Analisis Spasial Penyakit Kecacingan Soil Transmitted Helminth dengan Karakteristik Tanah Melalui Pendekatan Geomorfologi di Kabupaten Bantul," Jurnal Bumi Indonesia, Vol. 5, no.1, pp.1-9, 2016.

[3] A.R. Noviastuti, "Infeksi Soil Transmitted Helminths," Majority, Vol.4, no.8, pp.107-116, 2015.

[4] S. Suluwi, F. Rezal, dan C.S. Ismail, "Pengaruh penyuluhan dengan Metode Permainan Edukatif Sukata terhadap pengetahuan, sikap, dan tindakan tentang pencegahan penyakit cacingan pada siswa kelas IV dan V SD Negeri 1 Mawasangka Kabupaten Buton Tengah Tahun 2016," JIMKESMAS, Vol.2, pp. 1-10, 2017.

[5] U. Mahmudah, "Hubungan Sanitasi Lingkungan Rumah terhadap Kejadian Infeksi Kecacingan pada Anak Sekolah Dasar," Jurnal Ilmu Gizi, Vol. 10, no.1, pp. 32-39, 2017.

[6] E. Aritonang, dan A. Siagian, "The Relationship between Personal Hygiene and Helminthes Disease on Primary School Children in Terminal Disposal Waste Area," Atlantis Press, Vol.1, pp. 301-304, 2017.

[7] R. Winita, M.K. Huda, dan H. Astuti, "Infeksi Parasit Usus pada Anak dan Hubungannya dengan Pekerjaan sebagai Pemulung", Majalah Kedokteran UKI, Vol.32, no.3, pp.113-119 ,2016.

[8] H.I. Atta, U. Isah, and K.U. Amadi, "Prevalence of Soil Transmitted Helminthes in Children Attending Public Primary Schools in Samaru Zaria Nigeria," FTST Journal, Vol.4, no.1, pp. 32-35, 2018.

[9] I. Ramayanti, A. Makmun, "Soil Transmitted Helminths (STH) Infection Related Body Mass Index in Elementary School Students Sukawinatan Landfill Palembang City," Bioscientia Medicina : Journal of 
Biomedicine and Translational Research, Vol.2, no.3, pp. 8-15, 2018.

[10] I. Ramayanti, dan A. Ghiffari, "Factors of soil-transmitted helminths infections in children who live in the surrounding of the final disposal landfill of Sukawinatan Palembang," Journal of Physics: Conf. Series, 2019.

[11] O.P. Sari, T.I. Rosanti, dan L.D. Susiawan, "Hubungan Perilaku Kebersihan Perorangan dengan Kecacingan pada Siswa SD Susukan Kecamatan Sumbang Kabupaten Banyumas," Mandala of Health a Scientific Journal, Vol.12, no.1, pp. 120-129, 2017.

[12] N.L.G.D.R. Dewi dan D.A.A.S. Laksmi, "Hubungan Perilaku Higienitas Diri dan Sanitasi Sekolah dengan Infeksi Soil Transmitted Helminths pada Siswa Kelas III-VI Sekolah Dasar Negeri No. 5 Delod Peken Tabanan Tahun 2014," E-Journal Medika, Vol.6, no.5, pp. 1-4, 2017.

[13] U. Mahmudah, "Hubungan Sanitasi Lingkungan Rumah terhadap Kejadian Infeksi Kecacingan pada Anak Sekolah Dasar," Jurnal Ilmu Gizi, Vol. 10, no.1, pp. 32-39, 2017.

[14] D.M. Darlan, " Soil-transmitted helminth and its associated risk factors among schoolaged children," IOP Conf. Ser: Earth and Enviroment Science, Vol.305, pp. 1-6, 2019.

[15] A.S. Prabandari, V.D. Ariwarti, R. Pradistya, dan M.M.S. Sari, "Prevalensi Soil Transmitted Helminthiasis pada Siswa Sekolah Dasar di Kota Semarang," Avicenna: Journal of Health Research, Vol.3, no.1, pp. 1-10, 2020.

[16] S.A.A. Suryantari, A.B.S. Satyarsa, I.G.N.B.R.M. Hartawan, I.K.Y. Parastuta, dan I.M. Sudarmaja, "Prevalence, Intensity And Risk Factors Of Soil Transmitted Helminths Infections Among Elementary School Students In Ngis Village, Karangasem District, Bali," Indonesian Journal of Tropical Infectious Disease, Vol.7, no.6, 2019.

[17] N. Yuwono, S.S. Pasulu, D. Husada, dan S. Basuki, "Prevalence Of Soil Transmitted Helminthiasis Among Elementary Children In Sorong District West Papua," Indonesian Journal of Tropical Infectious Disease, Vol.7, no.4, pp. 86-91, January-April 2019.

[18] I.O. Ohuche, A.C. Ayuk, A.C. Ubesie, J.U. Onu, B.C. Ibe, "Soil-transmitted helminthiasis: A neglected tropical disease among urban slum dwelling school-aged children of a sub-Saharan African city," Nigerian Postgraduate Medical Journal, Vol.27, no.3, pp. 184-189, 2020.

[19] C.C. Winerungan, M.H.S. Angle, dan J.P.W. Greta, "Infeksi Parasit Usus pada Penduduk di Sekitar Tempat Pembuangan Akhir Sumompo Kota Manado," Jurnal Biomedika, Vol. 12, no.1, pp. 61-67, 2020.

[20] E. Roebiakto, dan J.S. Yohanes, "Risiko Infeksi Kecacingan pada Penambang Intan Tradisional di Kecamatan Cempaka Kota Banjarbaru," MLTJ, Vol.2, no.1, pp. 17-24, 2016.

[21] M. Salim, "Adat Sebagai Budaya Kearifan Lokal untuk Memperkuat Eksistensi Adat ke Depan," $A l$ Daulah, Vol.5, no.2, pp. 244-255, 2016.

[22] R.U. Ali, dan D. Affandi D, "Hubungan Personal Hygiene dan Sanitasi Lingkungan dengan Angka Kejadian Cacing (Soil Transmitted Helminths ) pada Petani Sayur di Kelurahan Maharatu Kecamatan Marpoyan Damai Kota Pekanbaru," Dinamika Lingkungan Indonesia, Vol.3, no.1, pp.16-23, 2015.

[23] M. Assefa, A. Kumie A, " Assessment of factors influencing hygiene behaviour among school children in Mereb-Leke District, Northern Ethiopia: a cross-sectional study," BMC Public Health, Vol. 14, no. 1000, pp. 8, 2014.

[24] S. Annisa, Dalilah, dan A. Chairil, "Hubungan Infeksi Cacing Soil Transmitted Helminths (STH) dengan Status Gizi pada Siswa Sekolah Dasar Negeri 200 Kelurahan Kemasrindo Kecamatan Kertapati Kota Palembang," Majalah Kedokteran Sriwijaya, Vol. 50, no.2, pp. 92-104, 2018.

[25] R. Suharmiati, "Mengungkap Kejadian Infeksi Kecacingan pada Anak Sekolah Dasar (Studi Etnografi di Desa Taramanu Kabupaten Sumba Barat)," Buletin Penelitian Sistem Kesehatan, Vol.21, no.3, pp. 212218, 2018.

[26] N. Andini, dan B. Utomo, "Hubungan antara Personal Hygiene dengan Kejadian Kecacingan Murid MI Ma'arif Nu Banteran Kecamatan Sumbang Kabupaten Banyumas Tahun 2017," Jurnal Kesehatan Lingkungan, Vol.37, no.32, pp.101-239, 2017.

[27] Suraini, Kaselawaty, dan F. Wahyuni, "Pengaruh Pengetahuan dan Personal Hygiene Terhadap Kejadian Infeksi Cacing pada Murid SDN 50 Kampung Jambak Padang," Prosiding Seminar Kesehatan Perintis, Vol.1, no.1, 2018.

[28] R. Aisyah, Z.P. Elshiana, I.P. Octaviani, O.E. Mardlotillah, "Hubungan Tingkat Pengetahuan dan Personal Higiene dengan Insidensi Penyakit Kecacingan pada Siswa Sekolah Dasar di Kartasura," 
Publikasi Ilmiah UMS, Vol. 13, pp. 131-138, 2019.

[29] K.Y.D. Pratama,dan M. Sudarmaja, "Hubungan Antara Perilaku Berisiko Terhadap Prevalensi Infeksi Soil-Transmitted Helmitnhs Pada Siswa Sd 2 Padangbulia," Directory Of Open Access Journals, Vol.7, No.8, pp.1-7, 2018.

[30] A. Wulandari, I. Saleh, dan Siliviana, "Factors Related To Worm Infection (Soil Transmitted Helminth) And Learning Achievement Among Elementary Students At Work Area Of Puskesmas Punggur," Jumantik, Vol.2, no.4, 2017.

[31] E.A. Farida, S.Z. Salim, M.D. Masyithoh, A.M. Charisma, dan K.I. Wahyuni, "Hubungan Kebersihan Personal dengan Infeksi Cacing Soil Transmitted Helminth (STH) pada Feses Anak SDN 1 Kedamean Kabupaten Gresik, J-Pham, Vol. 2. no.2, 2019.

[32] S. Sandy, S. Sri, Soeyoko, "Analisis Model Faktor Risiko yang Mempengaruhi Infeksi Kecacingan yang Ditularkan Melalui Tanah pada Siswa Sekolah Dasar di Distrik Arso Kabupaten Keerom, Papua," Media Litbangkes, Vol.25, no.1, pp. 1-14, 2015.

[33] N. Rahayu, M. Ramdani, "Faktor Risiko Terjadinya Kecacingan di SDN Tebing Tinggi di Kabupaten Balangan Provinsi Kalimantan Selatan," Jurnal Buski, Vol.4, no.3, pp. 150-154, 2013.

[34] N.A. Kusumawardani, E. Sulistyaningsih, C. Komariah, "Hubungan Sanitasi Lingkungan dengan Kejadian Infeksi Soil Transmitted Helminths pada Anak Sekolah Dasar di Jember," e-Journal Pustaka Kesehatan, Vol.7, no.1, 2019.

[35] L. Sofiana, E. Gustina, Y. Wardani, T. Halimatusa'diyah, "Environmental Factors and Helminth Infections Among Elementary Students," Atlantis Press, Vol.24, 2019.

[36] N. Rahayu, M. Ramdani, "Faktor Risiko Terjadinya Kecacingan di SDN Tebing Tinggi di Kabupaten Balangan Provinsi Kalimantan Selatan," Jurnal Buski, Vol.4, no.3, pp. 150-154, 2013.

[37] Yusmiati, "Dampak Keberadaan Tempat Pembuangan Akhir (Tpa) Muara Fajar Terhadap Sosial Ekonomi Masyarakat Di Kelurahan Muara Fajar Kecamatan Rumbai Kota Pekanbaru," Jurnal Online Mahasiswa Fakultas Ekonomi Universitas Riau, vol. 4, no. 1, Feb. 2017, pp. 172-186, 2017.

[38] I.A. Simon-Oke, O.J. Afolabi, dan E.T. Obimakinde, "Parasitic contamination of water sources in Akure Ondo State Nigeria," JoBAZ. Vol.81, no.50, 2020.

[39] N.F. Ugochi, and A.O. Moses, "Parasites Associated With Houseflies From Some Dump Sites In Ilisan And Ikenne Ogun State Southwest Nigeria," EJPMR, Vol. 7, no.1, 61-65, 2020.

[40] P.A. Muslimah, "Faktor-Faktor yang Berhubungan dengan Kejadian Infeksi Cacing pada Pekerja Armada Mobil Sampah di Kota Makassar," Universitas Islam Negeri Alauddin Makassar, 2019.

[41] M.I. Su, V.R.C. Warouw, K.L.Theffie, "Analisis Kualitas Air di Sekitar Situs TPA Sumompo Kota Manado," COCOS, Vol.1, no.5, 2017.

[42] A. Rahmi, E. Bambang, "Identifikasi Pengaruh Air Lindi (Leachate) terhadap Kualitas Air di Sekitar Tempat Pembuangan Akhir (TPA) Tanjung Belit," APTEK, Vol.11, no.1, pp. 1-6, 2019.

[43] A. Axmalia, A.M. Surahma AM, "The Impact of Landfilss Toward Publich Health," KESKOM, Vol.6, no.2, pp. 171-176, 2020.

[44] Z. Anggraini, J. Susanto, "Manajemen Persampahan di Kecamatan Rimbo Tengah Kabupaten Bungo," TRANSPARANSI, Vol.2, no.2, pp.201-210, 2019. 